\title{
Avaliação Tecnológica de Kit para Monitoramento Automático de Amostras Biológicas em Incubadoras
}

\section{Technological Evaluation of Kit for Automatic Monitoring of Biological Samples in Incubators}

\author{
Lívia Pereira de Araújo ${ }^{1}$ \\ Victor Seabra Dornas ${ }^{1}$ \\ Grace Ferreira Ghesti ${ }^{1}$ \\ ${ }^{1}$ Universidade de Brasília, Brasilia, DF, Brasil
}

\begin{abstract}
Resumo
O presente artigo se propõe a realizar uma avaliação tecnológica de um kit para monitoramento automático de amostras biológicas em incubadoras, equipado com um sistema de controle para iluminação, aquisição, armazenamento e transmissão de imagens. Situa-se no campo dos equipamentos laboratoriais para monitoramento de amostras biológicas para análises realizadas nas áreas médica, biológica, veterinária e farmacológica. Trata-se de um pedido de patente denominado "Kit para monitoramento automático de amostras biológicas em incubadoras, com controle de iluminação, aquisição, armazenamento e transmissão de imagens" depositado junto ao Instituto Nacional da Propriedade Industrial (INPI) em 26 de outubro de 2015 de titularidade da Fundação Universidade de Brasília (FUB) e da empresa Eletrospitalar comércio e assistência técnica, possuindo o número BR 1020150271000.
\end{abstract}

Palavras-chave: Prospecção Tecnológica. Equipamento Médico. Antibiograma.

\begin{abstract}
This paper proposes to perform a technological evaluation of a kit for automatic monitoring of biological samples in incubators, equipped with a control system for illumination, acquisition, storage and transmission of images. It is located in the field of laboratory equipment for monitoring biological samples for analysis performed in the medical, biological, veterinary and pharmacological areas. This is a patent application called "Kit for automatic monitoring of biological samples in incubators, with lighting control, acquisition, storage and transmission of images" filed with the National Institute of Industrial Property (INPI) on October 26, 2015. owned by the University of Brasilia Foundation (FUB) and the company Eletrospitalar commerce and technical assistance with the number BR 1020150271000.
\end{abstract}

Keywords: Technological Prospecting. Medical equipment. Antiogram.

Área Tecnológica: Prospecção Tecnológica. Propriedade Intelectual. 


\section{Introdução}

Os estudos destinados ao controle de infecções estão cada vez mais modernos e a realização de estudos por meio de culturas de material biológico, como bactérias, fungos, células, entre outros, é uma prática amplamente utilizada na obtenção de diagnósticos clínicos (LEVY, 2004). A utilização desse material biológico normalmente depende do cultivado em câmaras especiais, também conhecidas como incubadoras, que possuem a capacidade de controlar a temperatura, a umidade e os demais fatores de forma a criar um ambiente favorável ao desenvolvimento do objeto estudado (CALUSNI; BARTELEGA; BOTTINI, 2013). A placa de ágar é um meio físico de proliferação de culturas muito utilizada. Nessa placa estão presentes nutrientes, aminoácidose sais específicos, de acordo com o metabolismo do micróbio em análise (ANDRADE et al., 2015).

Um procedimento para realização de teste microbiológico é o antibiograma no qual são utilizados discos de difusão com antibióticos no meio de cultura em placa de ágar. A importância dos exames antibiograma é evidente para a formulação de novas drogas e medicamentos de controle microbiano e de tratamento de infecções. Com esse exame é possível realizar a avaliação da sensibilidade de microrganismos a diferentes tipos de substâncias químicas inibidoras ou retrativas do crescimento de certos micro-organismos, assim conhecidas como substâncias antimicrobianas. Pode-se citar como exemplos dessas substâncias os famosos antibióticos adquiridos em farmácias mediante a apresentação de receituário médico, que atuam no tratamento de infecções bacterianas (BAUER et al., 1966).

A análise da susceptibilidade aos antimicrobianos é feita por meio da avaliação dos efeitos provocados pelos antibióticos, presentes nos discos de difusão, depositados na cultura bacteriana cultivada em placa de Petri (ANDRADE et al., 2015). É possível encontrar no mercado de equipamentos médicos diferentes tipos de antibiogramas, como os de disco-difusão, microdiluição em caldo e o E test. O antibiograma de disco-difusão é o mais utilizado no Brasil e em boa parte dos países por se tratar de um equipamento com menor custo e de menor complexidade (COSTA, 2014). Esse aparelho é capaz de realizar testes in vitro, utilizando-se uma placa de Petri, na qual se aplica um disco de papel de filtro impregnado com antimicrobiano à superfície do ágar em que os microrganismos foram disponibilizados. Dessa forma, cada antimicrobiano irá formar uma circunferência de inibição, e o diâmetro dessa circunferência é utilizado para se fazer a classificação do disco em Resistente (R), Intermediário (I) ou Sensível (S) (BROCK, 1966 apud COSTA, 2014).

A medição do diâmetro dos halos é normalmente realizada por especialistas por meio da medição utilizando-se uma régua milimétrica. Essa medição é essencial para aferição dos resultados do exame antibiograma e, portanto, deve ser realizada com a maior precisão possível. A execução manual das medições, contudo, é dificultada pela: sobreposição dos halos de inibição; formulação heterogênea das circunferências; parcial atuação do antimicrobiano; formação de halos secundárias; e por possíveis adversidades na semeação dos microrganismos (COSTA, 2014). Todos esses fatores são limitantes da medição manual e, por muitas vezes, tornam impossível a realização do exame antibiograma laboratorial.

Para resolver tal problemática, algumas soluções foram estudadas na literatura, propondo-se diferentes métodos de automatização das medições na persecução dos exames antibiogramas, por meio da aplicação de técnicas de processamento de imagens. O objetivo desses métodos é simplificar o processo de leitura dos dados e evitar as variações nas interpretações do espe- 
cialista observador, decorrentes da medição manual (LIVERMORE et al., 2002). Hejblum et al. (1993) apresentam uma solução para identificação automática dos halos de inibição, sem, contudo, propor estratégias para contornar adversidades como a sobreposição de halos e a falta de homogeneidade da circunferência.

Gavoille, Bardy e Andremont (1994) tentam resolver os problemas não previstos no método proposto por Hejblum e formulam uma detecção por meio da diferença de textura das bordas. Contudo, nesse método dos autores é utilizado apenas a saturação de pixels para localização dos discos. Já Legrand, Aho e Dusserre (1995) trazem resultados obtidos por meio de método por eles desenvolvido sem descrever, contudo, como alcançar tais resultados. O Oxoid Aura Image System é um sistema utilizado para os exames de antibiograma e tem demonstrado resultados interessantes, apesar de suas técnicas não terem sido totalmente divulgadas, dificultando a possibilidade de reprodução e de aplicação do método proposto (ANDREWS; BOSWELL; WISE, 2000).

Ao se procurar outros sistemas de automatização para realização do exame antibiograma, é possível encontrar trabalhos desenvolvidos com os aparelhos antibiograma do tipo microdiluição em caldo como, por exemplo, o método proposto por Backes et al. (1984). Deve-se ressaltar, entretanto, que os métodos que utilizam sistema de disco-difusão continuam sendo os mais difundidos, principalmente pelo fato de eles serem os de menor custo e de baixa complexidade de aplicação.

O presente artigo se propõe a realizar uma avaliação tecnológica de um kit para monitoramento automático de amostras biológicas em incubadoras, equipado com um sistema de controle para iluminação, aquisição, armazenamento e transmissão de imagens. Situa-se no campo dos equipamentos laboratoriais para monitoramento de amostras biológicas para análises realizadas nas áreas médica, biológica, veterinária e farmacológica. Trata-se de um pedido de patente denominado "Kit para monitoramento automático de amostras biológicas em incubadoras, com controle de iluminação, aquisição, armazenamento e transmissão de imagens" depositado junto ao Instituto Nacional da Propriedade Industrial (INPI) em 26 de outubro de 2015 de titularidade da Fundação Universidade de Brasília (FUB) e da empresa Eletrospitalar Comércio e Assistência Técnica, possuindo o número BR 1020150271000 (ANDRADE et al., 2015).

A tecnologia analisada refere-se a um sistema para a iluminação, aquisição e transmissão de imagens com aplicação na área da microbiologia clínica e veterinária que utiliza a técnica de monitoramento por meio de mosaico de imagens. Essa técnica, largamente utilizada em mapeamento geográfico, consiste em equipar uma aeronave com uma câmera, um localizador do tipo Global Positioning System (GPS) e uma unidade inercial. A aeronave sobrevoa uma determinada área, previamente dividida em setores, e, a partir desse sobrevoo, são coletadas imagens que serão utilizadas na composição do mosaico da área monitorada. As imagens geradas são identificadas pelas coordenadas geográficas de cada setor e combinadas por meio de um programa de computador, de forma a compor um mosaico de toda a área sobrevoada (ANDRADE et al., 2015).

Partindo do mesmo conceito, a invenção descrita no pedido de patente analisado realiza a captação de imagens por meio de dispositivos instalados dentro de uma incubadora e utiliza a técnica de composição de imagens em mosaico modificada e adaptada contendo um sistema eletrônico para monitoramento simultâneo com controle de iluminação, aquisição, armazena- 
mento $e$ transmissão de imagens, servindo como um equipamento complementar às incubadoras de cultura bacteriológica existentes atualmente no mercado (ANDRADE et al., 2015).

Sendo assim, a tecnologia refere-se ao kit para monitoramento de amostras biológicas em incubadoras disponíveis no mercado em que se acopla o kit composto de bandejas superior e inferior, construídas em metal, contendo um sistema embarcado microcontrolado instalado na parte elevada da bandeja superior em que estão dispostas as câmeras equipadas com um sensor de captura de imagem e uma fonte de iluminação superior e outra inferior, sendo que todos os componentes do kit são removíveis e adaptáveis ao interior da incubadora que está sendo utilizada e operam de forma independente a esta, conforme se verifica na Figura 1.

Figura 1 - Estrutura do kit para monitoramento de amostras biológicas em incubadoras
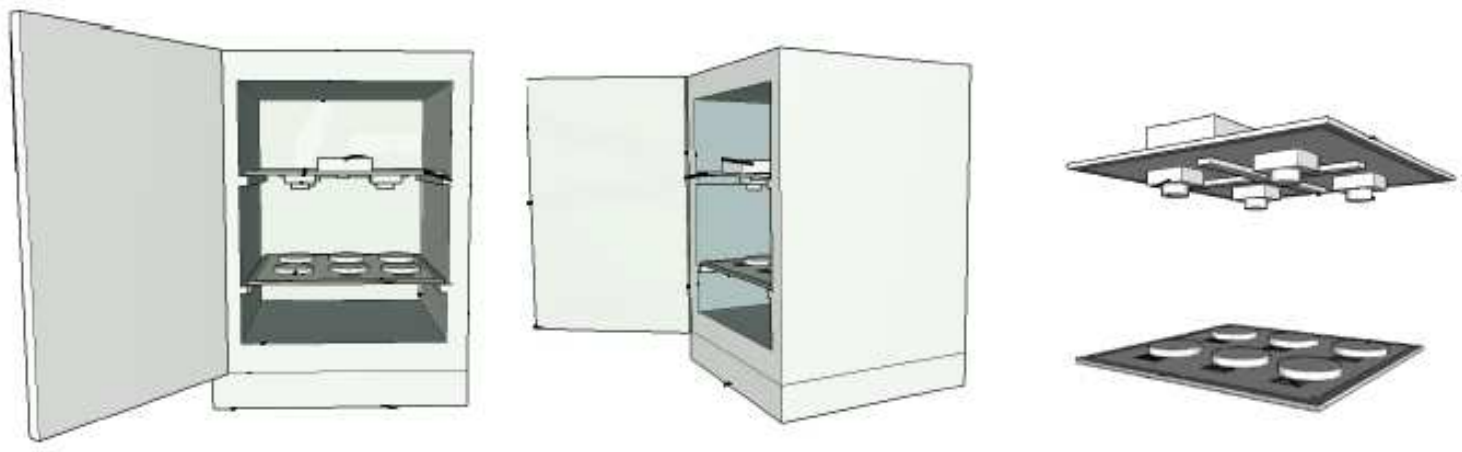

Fonte: Andrade et al. (2015)

\section{Metodologia}

O trabalho prospectivo foi realizado por meio da pesquisa documental no banco de dados de Patent Cooperation Treaty (WIPO, 2019) e de Orbit Intelligence Questel (ORBIT, 2019). Para definição da estratégia de busca, inicialmente utilizou-se o Patent Cooperation Treaty para realização de diferentes pesquisas, usando-se diferentes combinações de palavras-chave, operadores booleanos e caracteres de truncamento.

Dentro da plataforma escolhida selecionou a busca avançada e os campos título e resumo. Não foram acrescentados campos limitantes na busca em relação à data de depósito ou de publicação dos documentos. Para escolha das palavras-chave, buscou-se palavras que se remetem aos três campos principais que são abordados na tecnologia, sendo o equipamento antibiograma, a utilização desse tipo de equipamento para realização de pesquisas com microrganismos e bactérias e o método de automatização desenvolvido no âmbito do pedido de patente analisado.

Sendo assim, foram realizadas várias buscas com diferentes combinações a fim de buscar um melhor refinamento e evitar documentos patentários não correlatos com a tecnologia analisada, até que fosse possível se chegar a uma combinação de palavras-chaves, de operadores booleanos e de caracteres de truncamento que fosse adequada para o objetivo do estudo. Os resultados desse refinamento podem ser verificados na Tabela 1. 
Tabela 1 - Refinamento da busca - PatentScope: buscas em título e em resumo

\begin{tabular}{|c|c|c|}
\hline & CombinaçÃo & RESULTADOS \\
\hline 1 & $\begin{array}{l}\mathrm{TS}=(\text { incubator OR propagation OR incubation } \mathrm{OR} \text { chamber }) \\
\quad \mathrm{AND} T S=(\text { microbial OR bacterial) } \mathrm{AND} \mathrm{TS}=(\text { method })\end{array}$ & 32.342 \\
\hline 2 & $\mathrm{TS}=($ incubator $\mathrm{OR}$ incubation $) \mathrm{AND} T S=($ microbial $\mathrm{OR}$ bacterial $)$ AND TS $=($ method $)$ & 27.578 \\
\hline 3 & $\begin{array}{l}\mathrm{TS}=\text { (incubator OR propagation OR incubation } \mathrm{OR} \text { chamber) } \mathrm{AND} \mathrm{TS}=\text { (microbial } \\
\text { OR bacterial) AND TS }=\text { (method) AND TI }=\text { (Incubator OR propagation OR } \\
\text { incubation OR chamber) AND TI=(microbial OR bacterial) AND TI=(method) }\end{array}$ & 7.628 \\
\hline 4 & $\begin{array}{l}\mathrm{TS}=\text { (incubator } \mathrm{OR} \text { incubation } \mathrm{OR} \text { chamber }) \text { AND TS }=\text { (microbial } \mathrm{OR} \\
\text { bacterial) } \mathrm{AND} \mathrm{TS}=\text { (method) AND TI }=\text { (Incubator OR incubation OR } \\
\text { chamber) AND TI }=\text { (microbial OR bacterial) AND TI=(method) }\end{array}$ & 7.325 \\
\hline 5 & 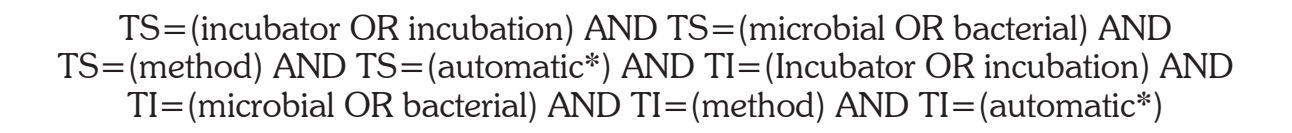 & 6.637 \\
\hline 6 & 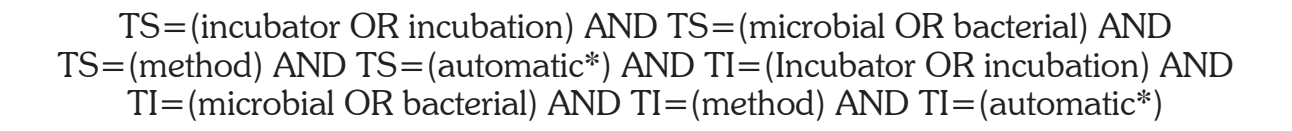 & 1.391 \\
\hline
\end{tabular}

Fonte: Elaborada pelos autores deste artigo (2020)

Após o refinamento da busca, definiu-se como combinação mais adequada de palavras-chave, de operadores booleanos e de caracteres de truncamento a combinação "(incubator OR incubation) AND (microbial OR bacterial) AND (method) AND (automatic*)", utilizados em título e em resumo.

Realizou-se também a identificação da Classificação Internacional de Patentes (CIP), conforme se verifica na Tabela 2 , de forma a garantir que os resultados estejam relacionados ao campo da invenção avaliada.

Tabela 2 - Descrição da Classificação Internacional de Patentes (CIP)

\begin{tabular}{|c|c|}
\hline Código & DESCRIÇÃo \\
\hline $\mathbf{G}$ & Física. \\
\hline G08 & Sinalização. \\
\hline G08C & Sistemas de transmissão para valores medidos, sinais de controle ou similares. \\
\hline G08C 13/00 & $\begin{array}{l}\text { Disposições para influenciar a relação entre sinais na entrada e } \\
\text { na saída, por exemplo, diferenciação, retardamento. }\end{array}$ \\
\hline G08C 13/02 & $\begin{array}{l}\text { Para emitir um sinal constituindo uma função de dois ou } \\
\text { mais sinais, por exemplo, soma, produto. }\end{array}$ \\
\hline $\mathbf{H}$ & Eletricidade. \\
\hline H04 & Técnica de comunicação elétrica. \\
\hline \multirow[t]{2}{*}{ H04N } & Comunicação de imagens. \\
\hline & $\begin{array}{l}\text { Transmissão de imagens ou sua reprodução transitória ou permanente local } \\
\text { ou remotamente, por métodos envolvendo ambas as etapas a seguir: } \\
\text { - etapa (a): a digitalização de uma imagem, i.e. a análise de toda a superfície que contém } \\
\text { a imagem por meio de elementos individuais da imagem, e a obtenção de sinais elétricos } \\
\text { correspondentes, representativos da imagem, simultânea ou sucessivamente; e } \\
\text { - etapa (b): a reprodução de toda a superfície que contém a imagem pela reprodução dos } \\
\text { elementos individuais da imagem em que a imagem é definida por meio de sinais elétricos } \\
\text { correspondentes, representativos da imagem, simultânea ou sucessivamente. }\end{array}$ \\
\hline
\end{tabular}

Fonte: Elaborada pelos autores deste artigo (2020) 
A avaliação da tecnologia aplicou a metodologia de Gestão de Negócio para projetos de P\&D da Empresa Brasileira de Pesquisa Agropecuária (EMBRAPA), mais especificamente a etapa de avaliação da qualificação de tecnologias (portão 3), com algumas adaptações, na quais são analisados três critérios: a vantagem competitiva, a atratividade do mercado e a probabilidade de sucesso (GREENHALGH et al., 2017).

\section{Resultados e Discussão}

A partir dos resultados obtidos, por meio da aplicação dos procedimentos metodológicos adotados, foi possível reunir os dados para discussão em três grupos: mapeamento tecnológico, avaliação de qualificação da tecnologia e transferência de tecnologia. Esses três agrupamentos de dados e de discussões serão abordados a seguir.

\subsubsection{Mapeamento Tecnológico}

Realizada a busca por documentos patentários no PatentScope, foram encontrados ao todo 1.391 documentos. Obteve-se como principais países depositantes o Canadá, com o total de 327 (trezentos e vinte e sete) documentos patentários, seguido pela Austrália, com 325 (trezentos e vinte e cinco). Em seguida foram encontrados 301 (trezentos e um) depósitos de pedidos de patentes e de patentes por meio do Tratado Internacional em Matéria de Patentes (PCT) e 276 (duzentos e setenta e seis) documentos patentários depositados nos Estados Unidos da América. Também apareceram nos resultados países como Israel, Nova Zelândia e África do Sul, conforme se verifica no Gráfico 1. Tais países, contudo, não possuem um número tão expressivo de documentos patentários no seguimento avaliado.

Gráfico 1 - Principais países depositantes - PatenScope - palavras-chave TS=(Incubator OR incubation) $\mathrm{AND} T S=($ microbial OR bacterial) $\mathrm{AND} T S=($ method $)$ AND TS $=$ (automatic*) AND TI=(Incubator OR incubation) AND TI=(microbial OR bacterial) AND TI=(method) AND TI=(automatic*)

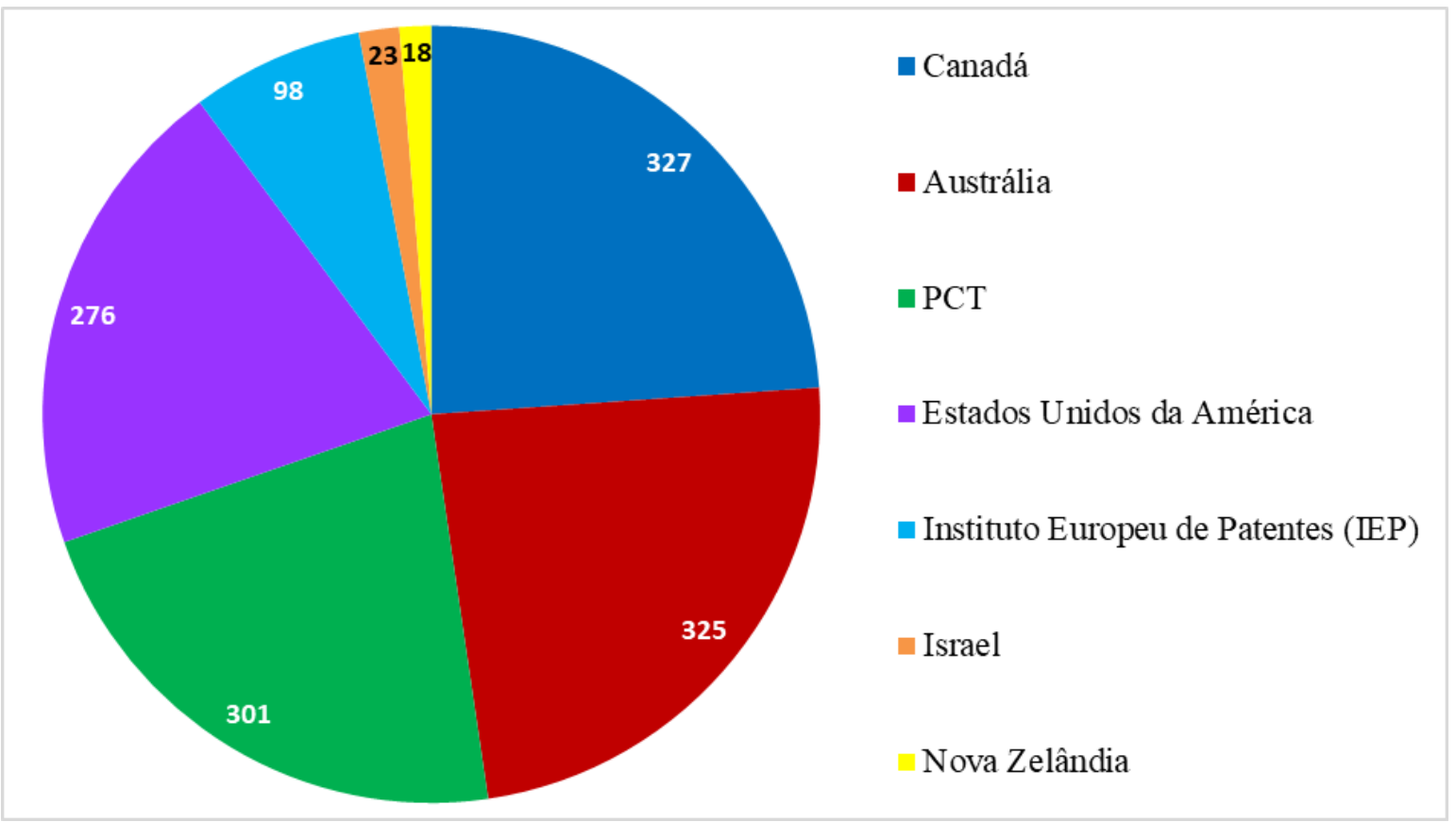

Fonte: Elaborado pelos autores deste artigo (2020) 
A menção dos Estados Unidos sendo um dos principais depositantes pode ser inferida como convencional, uma vez que, além de ser a maior economia do planeta, segundo relatório emitido pelo Fundo Monetário Internacional (FMI) (BRASIL, 2019), o país também é protagonista em rankings de maiores centros de tecnologia farmacêutica, conforme se verifica, por exemplo, no relatório da Forbes (2019). O país também representa mais de um quarto de todo o investimento mundial em Pesquisa, Desenvolvimento e Inovação (PD\&I), possuindo, isoladamente, 26,4\% de todo o investimento mundial em PD\&I, que corresponde a um total de 476,5 bilhões de dólares (DESJARDINS, 2018). O Escritório de Patentes Europeu aparece como o quarto maior depositante, por razões análogas. A surpresa se dá na alocação de pedidos de acordo com a estratégia de busca adotada com maior incidência no Canadá e na Austrália, décima primeira e décima terceira maiores economias, respectivamente, conforme aponta o relatório supracitado, uma vez que ambos os países não aparecem como maiores destaques em rankings de países com as maiores empresas do ramo (FORBES, 2019).

Outro resultado interessante que foi obtido a partir da busca realizada no banco de dados do PatentScope se refere às principais instituições que realizaram depósitos de documentos patentários referentes a equipamentos laboratoriais para monitoramento de amostras biológicas para análises realizadas nas áreas médica, biológica, veterinária e farmacológica, conforme pode-se verificar por meio dos dados do Gráfico 2.

Gráfico 2 - Principais instituições depositantes - PatenScope - palavras-chave TS=(Incubator OR incubation) AND TS $=$ (microbial OR bacterial) AND TS $=$ (method) AND TS $=$ (automatic*) AND TI $=$ (Incubator OR incubation) $\mathrm{AND} T \mathrm{TI}=$ (microbial $\mathrm{OR}$ bacterial) $\mathrm{AND} \mathrm{TI}=$ (method) AND $\mathrm{TI}=($ automatic*)

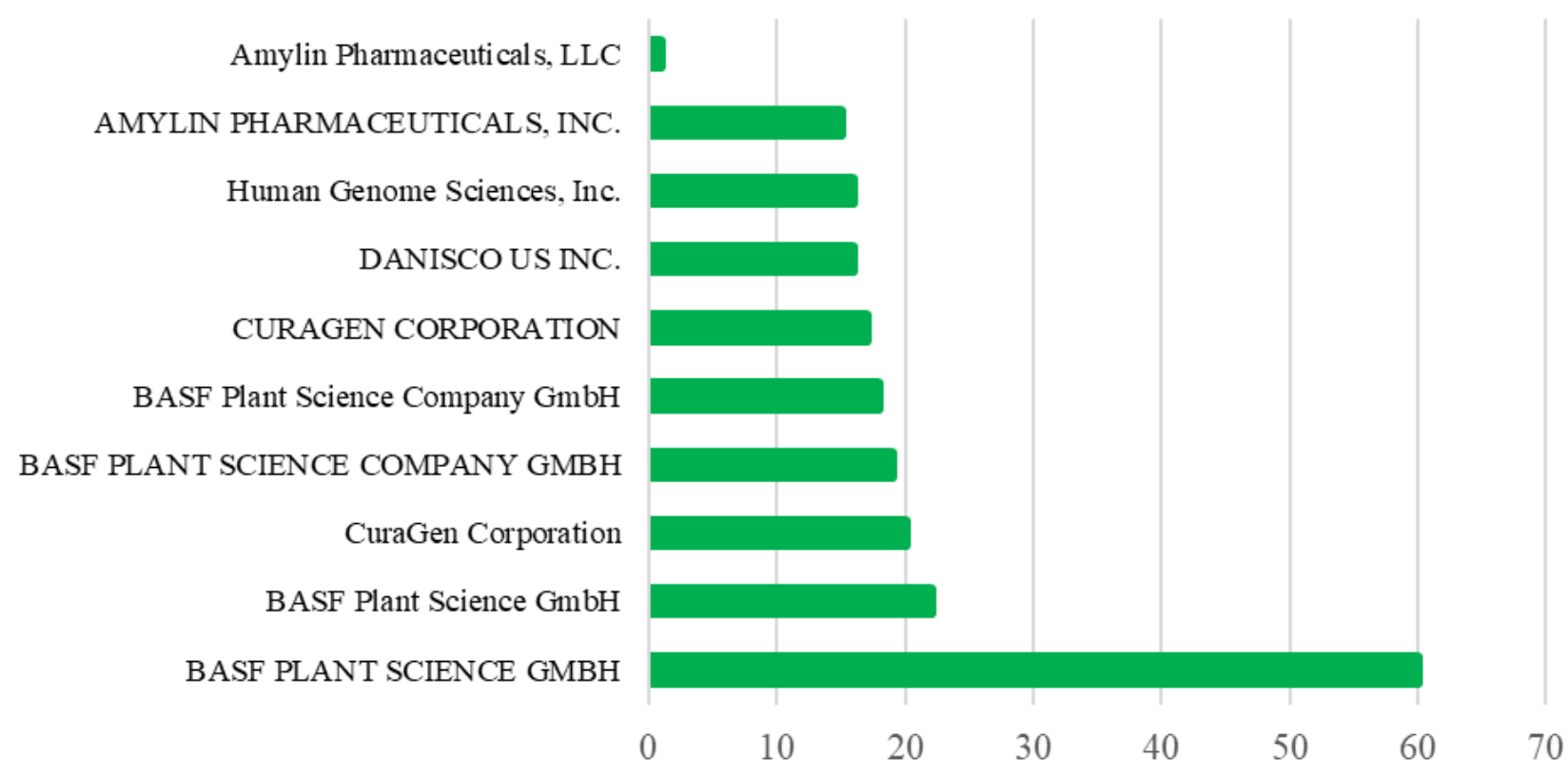

Fonte: Elaborado pelos autores deste artigo (2020)

Verifica-se que a empresa "BASF Plant Science" aparece como maior instituição depositante. Conforme registra o site Wikipedia (WIKIPEDIA et al., 2019), a empresa alemã BASF é líder mundial na produção química com faturamento anual estimado em aproximadamente 6.078 bilhões de Euros. Tal fato corrobora com a eficácia da estratégia de pesquisa adotada no presente artigo. De acordo com o sítio oficial da empresa, a BASF mantém diversas fábricas 
em território brasileiro, sendo as principais delas sediadas em Guaratinguetá, São Bernardo do Campo, Indaiatuba e Jacareí, sendo todos municípios paulistanos (BASF, 2017).

Em informativo de imprensa, a BASF informou que mantém no município alemão de Limburgerhof a maior fábrica de agentes biológicos do mundo, com mais de três mil tipos de microrganismos armazenados e utilizados no desenvolvimento de alta tecnologia. No mesmo relatório, a empresa informa ainda que no ano de 2016 investiu mais de 2 bilhões de Euros em pesquisa e desenvolvimento nessa área (BASF, 2019).

Mais um dado importante a ser discutido, obtido a partir da busca realizada no banco de dados do PatentScope, diz respeito aos principais inventores encontrados.

Gráfico 3 - Principais inventores - PatenScope - palavras-chave TS=(Incubator OR incubation) AND $\mathrm{TS}=($ microbial $\mathrm{OR}$ bacterial $)$ AND TS $=($ method $)$ AND TS $=($ automatic $*)$ AND TI $=($ Incubator OR incubation) $\mathrm{AND} \mathrm{TI}=\left(\right.$ microbial $\mathrm{OR}$ bacterial) $\mathrm{AND} \mathrm{TI}=($ method $)$ AND TI$=$ (automatic $\left.{ }^{*}\right)$

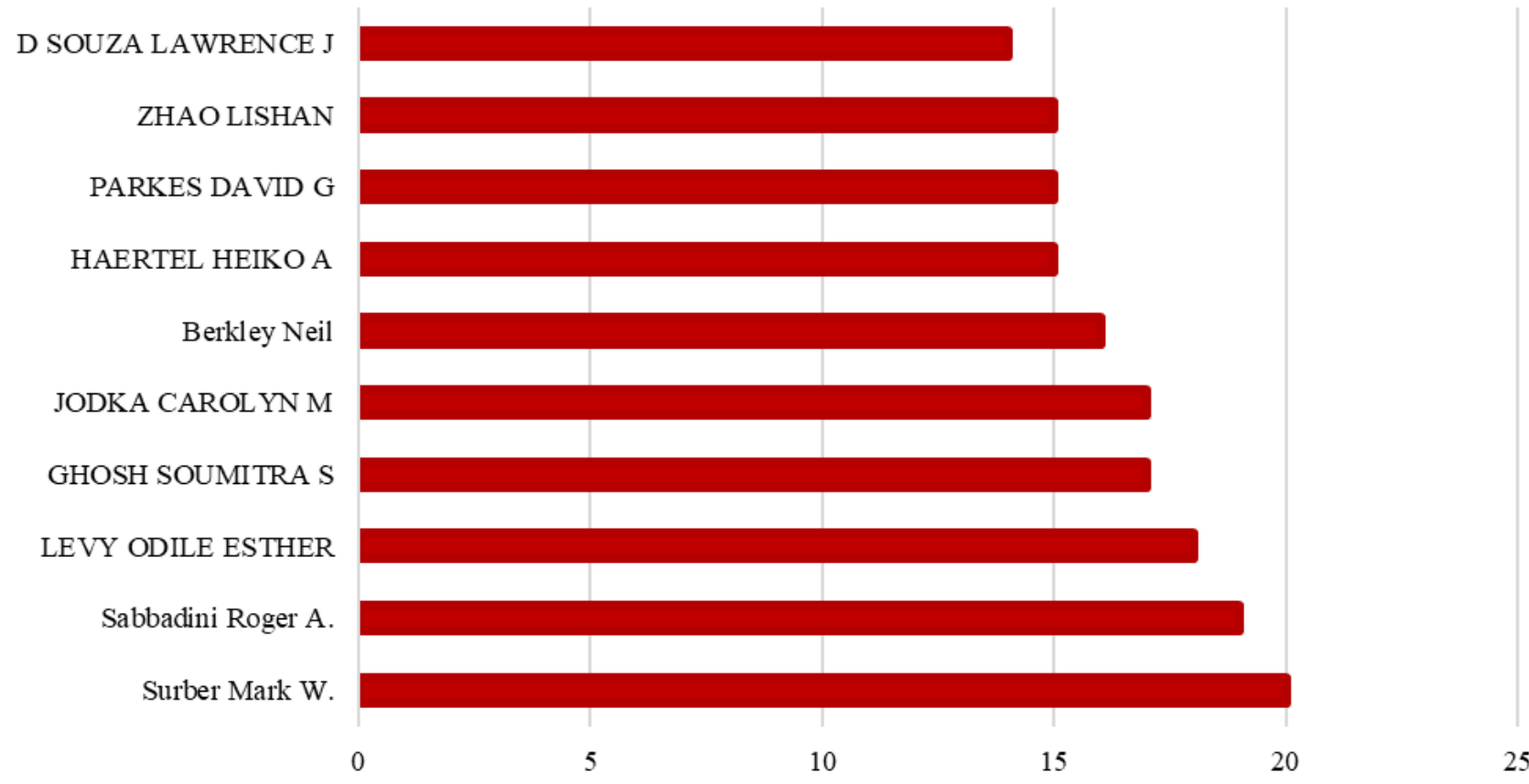

Fonte: Elaborado pelos autores deste artigo (2020)

De acordo com a plataforma ReasearchGate, Surber Mark W. é PhD com mais de 20 anos de experiência no desenvolvimento de fármacos e notória atividade no mercado empresaria (RESEARCHGATE, 2019a). Roger Sabbadini A. é professor emérito na Universidade de San Diego (RESEARCHGATE, 2019b).

O perfil profissional do professor Sabbadini corresponde ao perfil dos autores da tecnologia aqui prospectada, uma vez que ambos possuem perfil integralmente acadêmico. Já o perfil do professor Mark, embora apresente uma extensa carreira profissional como CEO no mercado privado, também se trata de alguém que percorreu todos os campos da vida acadêmica, sendo um $\mathrm{PhD}$.

Utilizando-se a base de dados Orbit Intelligence Questel com a combinação de palavras-chave "(incubator OR incubation) AND (microbial OR bacterial) AND (method) AND (automatic*)" foram obtidos 686 (seiscentos e oitenta e seis) documentos patentários. Observando o Gráfico 4, pode-se ver os dados obtidos a respeito do status legal dos documentos patentários 
encontrados. Foram encontrados 170 documentos pendentes de análise formal ou técnica, 164 documentos concedidos, ou seja, que já se tornaram patentes, e os demais referem-se a documentos patentários indeferidos, arquivados ou que já tiveram o seu prazo de proteção expirado.

Gráfico 4 - Status legal dos documentos patentários - Orbit Intelligence Questel - com a combinação de palavras-chave "(incubator OR incubation) AND (microbial OR bacterial) AND (method) AND (automatic*)"

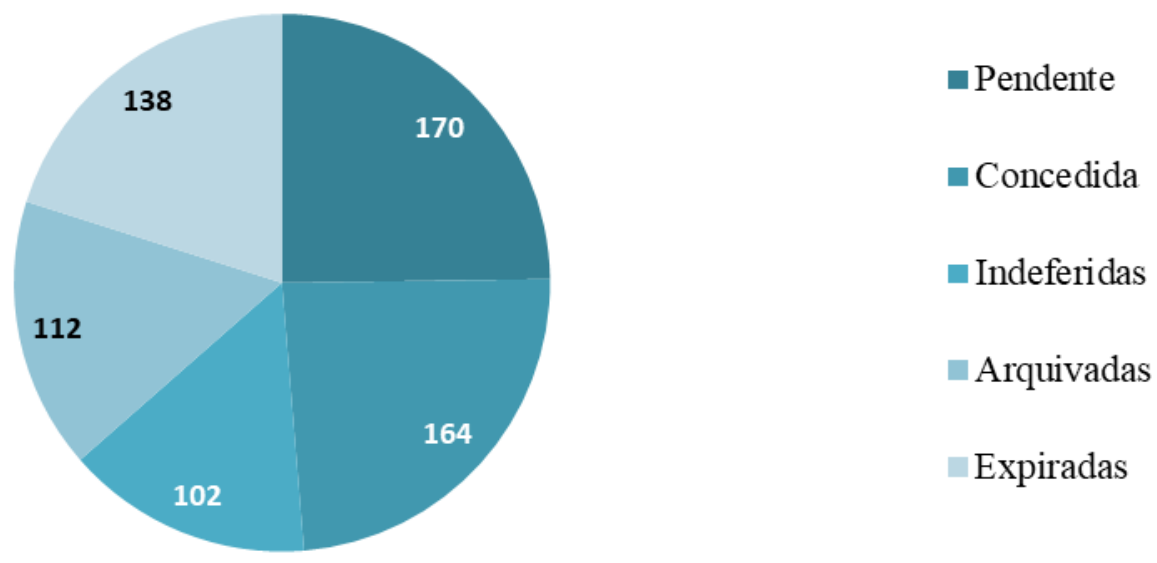

Fonte: Elaborado pelos autores deste artigo (2020)

\subsection{A Avaliação de Qualificação de Tecnologia}

A avaliação de qualificação de tecnologia foi realizada utilizando-se a metodologia exposta no livro Gestão de negócios em projetos de $P \& D$, de autoria da Embrapa. Tal metodologia de avaliação de tecnologias para o mercado baseia-se em um parâmetro de classificação quantitativo, com escala sugerida de 5 a 1 (GREENHALGH et al., 2017). A análise da tecnologia "Kit para monitoramento automático de amostras biológicas em incubadoras, com controle de iluminação, aquisição, armazenamento e transmissão de imagens" indicou que essa tecnologia possui uma vantagem competitiva relativamente interessante, mas apresenta uma atratividade de mercado abaixo da média, tendo em vista a sua proteção ter sido realizada somente no Brasil, que não apresentou, na prospecção previamente realizada, grande interesse por parte da indústria correlata à tecnologia, havendo, portanto, uma barreira inicial para entrada da tecnologia no mercado brasileiro.

Além disso, a tecnologia apresenta-se como uma inovação que se caracteriza como seguidora de uma tecnologia dominante, isto é, trata-se de uma alternativa a produtos já existentes no mercado. Constatou-se que trabalhar com a tecnologia no atual estágio em que ela se encontra pode significar uma baixa probabilidade de sucesso, pois essa tecnologia ainda precisa celebrar parcerias para a realização de testes em escala que possibilite a comprovação de sua efetividade em termos de mercado.

\subsection{Transferência de Tecnologia}

É importante mencionar inicialmente que a transferência de tecnologia é todo o intercâmbio de conhecimento e habilidades tecnológicas entre duas ou mais instituições, visando à inserção dessa tecnologia em ambiente produtivo, industrial, social ou organizacional. Esse intercâmbio 
pode ser formalizado por meio da celebração de contratos de pesquisa e desenvolvimento, serviços de consultoria, formação profissional, inicial e continuada, licenciamento de patentes, marcas e processos industriais (MELO; LEITÃO, 2010).

Cabe ressaltar que a tecnologia foi desenvolvida em parceria com uma empresa de venda, fabricação e manutenção de equipamentos médicos, a Eletrospitalar Comércio e Assistência Técnica. Por meio de consulta realizada no site da Receita Federal, utilizando-se o número do Cadastro Nacional de Pessoa Jurídica (CNPJ) disponível no sítio eletrônico oficial da empresa (ELETROSPITALAR COMÉRCIO E ASSISTÊNCIA TÉCNICA, 2019), foi possível se obter o comprovante de inscrição e de situação cadastral. Nele consta que a empresa possui como código e descrição da atividade econômica principal o número 32.50-7-01, referente à fabricação de instrumentos não eletrônicos e de utensílios para uso médico, cirúrgico, odontológico e de laboratório. Como código e descrição das atividades econômicas secundárias, a empresa possui o número 46.64-8-00, referente ao comércio atacadista de máquinas, aparelhos e equipamentos para uso odonto-médico-hospitalar; partes e peças; o número 33.12-1-02, relativo à manutenção e reparação de aparelhos e instrumentos de medida, teste e controle; o número 33.14-7-07, que diz respeito à manutenção e reparação de máquinas e aparelhos de refrigeração e ventilação para uso industrial e comercial; e o número 26.60-4-00, referente à fabricação de aparelhos eletromédicos e eletroterapêuticos e equipamentos de irradiação.

Sendo assim, existe a possibilidade de realização de um licenciamento para que a própria empresa cotitular do pedido de patente possa produzir e vender a tecnologia. Além disso, por se tratar de desenvolvimento em conjunto com a empresa, a FUB poderá celebrar o contrato de licenciamento de tecnologia para uso e exploração comercial junto à Eletrospitalar com cláusula de exclusividade, sem a necessidade de chamamento público, conforme prevê a Lei de Inovação, Lei n. 10.973/2004 (BRASIL, 2004).

Deve-se levar em consideração que a proteção do pedido de patente realizada no Brasil não foi estendida a outros países, limitando-se apenas ao território nacional. Sendo assim, a princípio, a estratégia mais interessante seria a de continuar com a parceria já existente entre a FUB e a Eletrospitalar, uma empresa brasileira que já atua no ramo, existindo a possibilidade de prospectar editais de fomento para obtenção de recursos financeiros para início da produção da tecnologia ou até mesmo do desenvolvimento de melhoramentos.

\section{Considerações Finais}

A presente prospecção possibilitou a realização do mapeamento tecnológico em relação ao campo do pedido de patente em questão. Observou-se que entre os principais países depositantes estão o Canadá, a Austrália e os Estados Unidos da América. Também apareceram países como Nova Zelândia, Israel e África do Sul para realização da proteção de pedidos de patentes semelhantes ao analisado na presente prospecção, conduto com um número bem menor ao se comparar com os três países que mais tiveram depósitos de documentos patentários realizados.

Constatou-se também que a empresa "BASF Plant Science" aparece como maior instituição depositante, sendo uma empresa alemã, líder mundial na produção química com faturamento anual estimado em aproximadamente 6.078 bilhões de Euros e com diversas fábricas em território brasileiro, destacando-se as principais delas sediadas em Guaratinguetá, São Bernardo do Campo, Indaiatuba e Jacareí, todos municípios paulistanos. 
Foi possível identificar como principal inventor o $\mathrm{PhD}$ Surber Mark W., que possui mais de 20 anos de experiência no desenvolvimento de fármacos e com notória atividade no mercado empresarial. Em segundo lugar, identificou-se o Dr. Roger Sabbadini A., que é professor emérito na Universidade de San Diego.

$\mathrm{Na}$ análise sobre o grau de maturidade da tecnologia prospectada, identificou-se que ela se encontra em etapa de validação dos componentes da tecnologia em ambiente relevante, uma vez que a tecnologia possui protótipo capaz de gerar a integração dos componentes tecnológicos e o teste das aplicações desses componentes em um ambiente realístico. Já havendo, inclusive, a validação dos componentes do sistema ou processo vinculados ao programa de computador de processamento de imagens.

Por fim, na análise das possíveis estratégias para transferência de tecnologia, foi possível verificar que a continuidade na parceria já existente entre a FUB e a Eletrospitalar pode ser uma alternativa viável por se tratar de uma empresa brasileira que já atua no ramo, existindo a possibilidade de prospectar editais de fomento para obtenção de recursos financeiros para início da produção da tecnologia ou até mesmo do desenvolvimento de melhoramentos.

\section{Referências}

ANDRADE, Marcelino Monteiro de et al. Kit para monitoramento automático de amostras biológicas em incubadoras, com controle de iluminação, aquisição, armazenamento e transmissão de imagens. BR número 1020150271000, 26 out. 2015. Revista da Propriedade Industrial, [S.1.], n. 2417, 2 de maio de 2017. Disponível em: http://revistas.inpi.gov.br/rpi. Acesso em: 7 ago. 2019.

ANDREWS, J. M.; BOSWELL, F. J.; WISE, R. Evaluation of the oxoid aura image system for measuring zones of inhibition with the disc diffusion technique. Journal of Antimicrobial Chemother, [S.l.], v. 46, p. 535-540, 2000. Disponível em: https://academic.oup.com/jac/ article/46/4/535/739773. Acesso em: 8 ago. 2019.

BACKES, B. et al. Rapid antimicrobial susceptibility testing of Gram-negative clinical isolates with the AutoMicrobic system. Journal Of Clinical Microbiology, [S.I.], v. 19, n. 6, p. 744-747, 1984. American Society for Microbiology. DOI:http://dx.doi.org/10.1128/jcm.19.6.744-747.1984. Disponível em: https://www.ncbi.nlm.nih.gov/pmc/articles/PMC271177/pdf/jcm00131-0050.pdf. Acesso em: 13 abr. 2020.

BAUER, A. W. et al. Antibiotic Susceptibility Testing by a Standardized Single Disk Method.

American Journal Of Clinical Pathology, Oxford University Press (OUP), v. 45, n. 4, p. 493-496, $1^{\circ}$ abr. 1966. Disponível em: https://academic.oup.com/ajcp/article-abstract/45/4_ts/493/4821085?re directedFrom =fulltext. Acesso em: 7 ago. 2019.

\section{BASF (Alemanha). BASF oferece soluções biológicas inovadoras para controle de}

pragas. 2017. Disponível em: https://www.basf.com/br/pt/media/news-releases/2017/05/basf-oferecesolucoes-biologicas-inovadoras-para-controle-de-pra.html. Acesso em: 9 ago. 2019.

BASF (Alemanha) (Org.). BASF no Brasil. 2019. Disponível em: https://www.basf.com/br/pt/ careers/why-join-basf/basf-at-a-glance/basf-in-country.html. Acesso em: 9 ago. 2019.

BRASIL. Lei n. 10.973, de 2 de dezembro de 2004. Dispõe sobre incentivos à inovação e à pesquisa científica e tecnológica no ambiente produtivo e dá outras providências. Disponível em: http://www.planalto.gov.br/ccivil_03/_ato2004-2006/2004/lei/110.973.htm. Acesso em: 15 ago. 2019. 
BRASIL. Fundação Alexandre de Gusmão. Maiores Economias do Mundo: PIB em trilhões de US\$ - 2012-2019 - ordem decrescente de 2013. [2019]. Disponível em: http://www.funag.gov.br/ipri/ images/analise-e-informacao/01-Maiores_Economias_do_Mundo.pdf?source=post_page---------. Acesso em: 9 ago. 2019.

CALUSNI, Ana Lúcia Roscani; BARTELEGA, Maria José Franco Landi; BOTTINI, Paula Virginia. Microbiologia clínica para o controle de infecção relacionada à assistência à saúde. 2 . ed. Brasília, DF: Editora da Agência Nacional de Vigilância Sanitária, 2013. 48 p. Disponível em: https://w2.fop.unicamp.br/cibio/downloads/biosseguranca_manutencao_equipamentos_laboratorio_ microbiologia.pdf. Acesso em: 8 ago. 2019.

COSTA, Luan Felipe Rodrigues. Método automático para identificação da região de inibição e de rótulos alfanuméricos de antibióticos posicionados em antibiogramas por discodifusão. 2014. 62 f. Monografia (Especialização) - Curso de Engenharia Eletrônica, Faculdade UnB Gama (FGA), Universidade de Brasília, Brasília, 2014. Disponível em: http://bdm.unb.br/ handle/10483/7975. Acesso em: 7 ago. 2019.

DESJARDINS, Jeff. World Economic Forum: innovators wanted: these countries spend the most on r\&d. Innovators wanted: these countries spend the most on R\&D. 2018. Disponível em: https://www. weforum.org/agenda/2018/12/how-much-countries-spend-on-r-d/. Acesso em: 18 dez. 2018.

ELETROSPITALAR COMÉRCIO E ASSISTÊNCIA TÉCNICA (Brasil). Sobre a empresa. 2019. Disponível em: https://www.eletrospitalar.com.br/. Acesso em: 15 ago. 2019.

FORBES. 15 maiores empresas farmacêuticas do mundo. 2019. Disponível em: https://forbes.uol. com.br/listas/2015/07/15-maiores-empresas-farmaceuticas-do-mundo/\#foto9. Acesso em: 9 ago. 2019.

GAVOILLE, A.; BARDY, B.; ANDREMONT, A. Measurement of inhibition zone diameter in disk susceptibility tests by computerized image analysis. Comput. Biol. Med., [S.l.], v. 24, p. 179-188, 1994. Disponível em: https://www.sciencedirect.com/science/article/pii/0010482594900140. Acesso em: 8 ago. 2019.

GREENHALGH, André Augusto Moreira Silva et al. Gestão de negócios para projetos de P\&D. Brasília, DF: Embrapa, 2017. 26 p.

HEJBLUM, G. et al. Automated interpretation of disk diffusion antibiotic susceptibility tests with the radial profile analysis algorithm. In: PATHOL, A. J. C. (ed.). Journal of Clinical Microbiology. [S.l.: s.n.], 1993. p. 2.396-2.401. Disponível em: https://www.ncbi.nlm.nih.gov/pubmed/8408562. Acesso em: 7 ago. 2019.

LEGRAND, L. R.; AHO, L. S.; DUSSERRE, L. Antibigram automatic reading with a micro-computer based image processing system. Proceeding RC IEEE-EMBS 14th BMESI, [S.I.], 1995. Disponível em: https://ieeexplore.ieee.org/stamp/stamp.jsp?arnumber=511721. Acesso em: 8 ago. 2019.

LEVY, Carlos Emílio. Manual de microbiologia clínica para o controle de infecção em serviços de saúde. Brasília, DF: Editora Agência Nacional de Vigilância Sanitária, 2004. 381 p. Disponível em: https://bvsms.saude.gov.br/bvs/publicacoes/manual_microbiologia_completo.pdf. Acesso em: 8 ago. 2019.

LIVERMORE, D. M. et al. Multicenter evaluation of the vitek 2 advance expert system for interpretive reading of antimicrobial resistance tests. Journal of Antimicrobial Chemotherapy, [S.I.], v. 49, n. 2, p. 289-300, 2002. Disponível em: https://www.researchgate.net/publication/11543552 Multicentre_evaluation_of_the_VITEK_2_Advanced_Expert_System_for_interpretive_reading_of antimicrobial_resistance_tests. Acesso em: 7 ago. 2019. 
MELO, Herbart dos Santos; LEITÃO, Leonardo Costa. Dicionário Tecnologia e Inovação. Fortaleza: Sebrae, 2010. 120 p. Disponível em: https://pt.slideshare.net/leoclbox/dicionario-detecnologia-e-inovao. Acesso em: 11 jun. 2019.

ORBIT. Questel Orbit Intelligence: [Base de dados - Internet]. [2019]. Disponível em: https:// www.orbit.com/. Acesso em: 8 ago. 2019.

RESEARCHGATE (Estados Unidos) (org.). Mark Subber. 2019a. Disponível em: https://www. researchgate.net/profile/Mark_Surber2. Acesso em: 20 mar. 2020.

RESEARCHGATE (Estados Unidos) (org.). Roger Sabbadini. 2019b. Disponível em: https://www. researchgate.net/profile/Roger_Sabbadini2. Acesso em: 20 mar. 2020.

UOL. Governo Trump traça plano para importar fármacos do Canadá... - Veja mais em https://noticias.uol.com.br/ultimas-noticias/afp/2019/07/31/governo-trump-traca-plano-paraimportar-farmacos-do-canada.htm?cmpid=copiaecola. 2019. Disponível em: https://noticias. uol.com.br/ultimas-noticias/afp/2019/07/31/governo-trump-traca-plano-para-importar-farmacos-docanada.htm. Acesso em: 9 ago. 2019.

WIKIPEDIA et al. (Comp.). BASF. 2019. Disponível em: https://pt.wikipedia.org/wiki/BASF. Acesso em: $1^{\circ}$ mar. 2019.

WIPO - WORLD INTELLECTUAL PROPERTY ORGANIZATION. PatentScope. Base de dados internet. [2019]. Disponível em: https://patentscope.wipo.int/search/en/search.jsf. Acesso em: 8 ago. 2019.

\section{Sobre os Autores}

\section{Lívia Pereira de Araújo}

E-mail: livia.pa90@gmail.com

Mestre em Propriedade Intelectual e Transferência de Tecnologia para a Inovação pela UnB em 2019.

Endereço profissional: Campus Universitário Darcy Ribeiro, Edifício CDT, Sala do PROFNIT/UnB, Asa Norte, Brasília, DF. CEP: 70904-970.

\section{Victor Seabra Dornas}

E-mail: victor.seabra@gmail.com

Bacharel em Direito pela UNICEUB em 2009.

Endereço profissional: Campus Universitário Darcy Ribeiro, Edifício CDT, Sala do PROFNIT/UnB, Asa Norte, Brasília, DF. CEP: 70904-970.

\section{Grace Ferreira Ghesti}

E-mail: ghesti.grace@gmail.com

Doutora em Química pela UnB em 2009.

Endereço profissional: Campus Universitário Darcy Ribeiro, Edifício CDT, Sala do PROFNIT/UnB, Asa Norte, Brasília, DF. CEP: 70904-970. 